\title{
NIM1 Overexpression in Arabidopsis Potentiates Plant Disease Resistance and Results in Enhanced Effectiveness of Fungicides
}

\author{
Leslie Friedrich, ${ }^{1}$ Kay Lawton, ${ }^{1}$ Robert Dietrich, ${ }^{1}$ Michael Willits, ${ }^{1}$ Rebecca Cade, ${ }^{1}$ and John Ryals ${ }^{2}$ \\ ${ }^{1}$ Syngenta, 3054 Cornwallis Road, Research Triangle Park, NC 27709, U.S.A.; 'Paradigm Genetics, \\ 104 Alexander Drive, Research Triangle Park, NC 27709, U.S.A. \\ Submitted 21 December 2000; Accepted 8 May 2001.
}

\begin{abstract}
The NIM1 (for noninducible immunity, also known as $N P R 1)$ gene is required for the biological and chemical activation of systemic acquired resistance (SAR) in Arabidopsis. Overexpression of NIM1 in wild-type plants (hereafter referred to as NIM1 plants or lines) results in varying degrees of resistance to different pathogens. Experiments were performed to address the basis of the enhanced disease resistance responses seen in the NIM1 plants. The increased resistance observed in the NIM1 lines correlated with increased NIM1 protein levels and rapid induction of $P R 1$ gene expression, a marker for SAR induction in Arabidopsis, following pathogen inoculation. Levels of salicylic acid (SA), an endogenous signaling molecule required for SAR induction, were not significantly increased compared with wild-type plants. SA was required for the enhanced resistance in NIM1 plants, however, suggesting that the effect of NIM1 overexpression is that plants are more responsive to $\mathrm{SA}$ or a $\mathrm{SA}$-dependent signal. This hypothesis is supported by the heightened responsiveness that NIM1 lines exhibited to the SAR-inducing compound benzo(1,2,3)-thiadiazole-7-car-bothioic acid $S$ methyl ester. Furthermore, the increased efficacy of three fungicides was observed in the NIM1 plants, suggesting that a combination of transgenic and chemical approaches may lead to effective and durable disease-control strategies.
\end{abstract}

Systemic acquired resistance (SAR) is an inducible disease resistance response triggered by the formation of necrotic lesions resulting from pathogen attack (Hunt and Ryals 1996; Ryals et al. 1996). SAR is characterized by the coordinately induced expression of a set of so-called "SAR genes" and results in enhanced resistance to subsequent attack by a variety of pathogens (Uknes et al. 1992; Ward et al. 1991; White 1979). In plants where the SAR signal transduction pathway is blocked, the ability of the plant to protect itself from secondary infection is adversely affected and the response to primary infection may be affected as well. SAR-compromised plants can become susceptible to normally avirulent pathogens and, compared with wild-type plants, develop more severe disease symptoms when infected with virulent pathogens (Delaney et al. 1994; Delaney et al. 1995; Gaffney et al. 1993; Maher et

Corresponding author: R. Dietrich; Fax: +1-919-541-8585;

E-mail: bob.dietrich@syngenta.com al. 1994; Mauch-Mani, 1996; Pallas et al. 1996). SAR has been demonstrated in a range of plant species, emphasizing the importance of SAR as a general disease resistance response.

Salicylic acid (SA) is an essential component of the SAR signal transduction pathway in some plant species. Transgenic tobacco and Arabidopsis plants expressing the bacterial salicylate hydroxylase $(n a h G)$ gene cannot accumulate SA, resulting in a reduction in the local and systemic defense responses and a compromised resistance to viral, bacterial, or fungal pathogens (Bi 1995; Delaney et al. 1994; Gaffney et al. 1993). SAR can be activated in NahG plants by the chemical SAR activators dichloroisonicotinic acid (INA) and benzo(1,2,3)-thiadiazole-7-carbothioic acid S-methyl ester, commonly known as $\mathrm{BTH}$, indicating that these chemicals may activate the SAR pathway at the same point as, or downstream of, SA (Lawton et al. 1996; Vernooij et al. 1995). INA and BTH induce SAR in several plant species, providing protection against a number of pathogens (Friedrich et al. 1996; Gorlach et al. 1996; Lawton et al. 1996; Morris et al. 1998; Vernooij et al. 1995). BTH currently is being developed as a disease-control agent that protects crops by activating the SAR signal transduction pathway (Oostendorp et al. 2001).

To better understand the molecular mechanisms underlying SAR, several screens have been performed to identify mutants modified in the SAR response. In one approach, Arabidopsis mutants with constitutive SAR were identified. Such mutants exhibit constitutive disease resistance and elevated SAR gene expression. Among this class of mutants are the lesions simulating disease resistance $(l s d)$ (Dietrich et al. 1994; Weymann et al. 1995), accelerated cell death ( $a c d 2)$ (Greenberg et al. 1994), constitutive immunity ( $\mathrm{cim}$ ) (Lawton et al. 1993), constitutive pathogenesis-related (PR) gene expression (cpr) (Bowling et al. 1994; Bowling et al. 1997; Clarke et al. 1998), and suppressor of SA insensitivity (ssil) (Shah et al. 1999). Whereas the $l s d, a c d 2$, and ssil mutants develop spontaneous necrotic lesions, the cim, cprl, and cpr6 mutants do not have detectable lesions. Epistasis studies with these types of mutants contributed to the understanding of the role of necrosis on the activation of SAR and the role of SA in spontaneous cell death and facilitated the placement of some of the corresponding genes in the SAR signal transduction pathway (Ryals et al. 1996).

In a second approach, mutants unable to activate SAR in response to chemical inducers were identified (Cao et al. 1994; Delaney et al. 1995; Shah et al. 1997). In all three screens of this type, mutations in only one locus, noninducible immunity 
(niml), also known as no PR-gene expression (nprl), have been reported (Cao et al. 1997; Ryals et al. 1997; Shah et al. 1997). These results indicate that NIMI/NPRl is a key SAR regulator, acting downstream of SA and upstream of $P R$ gene expression. Furthermore, this same locus was identified in a screen designed to identify mutants with compromised pathogen resistance responses (Glazebrook et al. 1996). To date, 12 niml alleles have been identified in diverse mutant screens for plants showing altered disease resistance responses, underscoring the importance of this protein in SAR and plant health.

A promising approach toward developing disease-resistant plants is to exploit naturally occurring defense mechanisms. The validity of this approach has been demonstrated by the enhanced disease resistance observed in transgenic plants that overexpress defense genes such as NPRI (Cao et al. 1998) and NDRl (Repetti and Staskawicz 1998) in Arabidopsis and Prf in tomato (Oldroyd and Staskawicz 1998). We employed this strategy to generate plants with broad-spectrum disease resistance by overexpressing the NIMI gene in Arabidopsis. We found that a subset of the NIM1 lines exhibited constitutive resistance to a number of pathogens, which is consistent with the results of Cao et al. (1998). We extend these findings significantly by demonstrating that NIM1 plants are more responsive to SA (or a SA-dependent signal) and the chemical activator BTH. Finally, we demonstrate that NIM1 overexpression and fungicide treatment result in a synergistic reduction in fungal growth. These results suggest a regulatory model to explain previous findings that plant defense responses may contribute to fungicide efficacy (Molina et al. 1998).

\section{RESULTS}

\section{Generation of Arabidopsis plants overexpressing the NIM1 gene.}

Wild-type Arabidopsis Wassilewskija plants were transformed with a fragment of Arabidopsis genomic DNA containing the NIM1 gene and $1.4 \mathrm{~kb}$ pairs of a $5^{\prime}$ flanking sequence (Ryals et al. 1997). Thirty-eight independent transgenic lines were analyzed for NIM1 gene expression and resistance to Peronospora parasitica isolate Emwa, an oomycete pathogen causing downy mildew controlled by the induction of SAR in Arabidopsis. A majority of the plants demonstrated constitutive resistance to $P$. parasitica, although variability in the level of NIM1 gene expression and the degree of disease resistance was observed in the transgenic lines, possibly as a result of differences in T-DNA insertion positions. Seven transgenic lines, representing a range of resistant phenotypes, were selected for more detailed characterization. There were no visible effects of NIMI overexpression on uninoculated plants, with the exception of the resistant line 8C, which sometimes grew more slowly than Wassilewskija parental plants.

\section{Broad-spectrum disease resistance in NIM1 lines.}

The seven selected transgenic lines were challenged with a variety of virulent pathogens to determine whether overexpression of NIMI alters susceptibility to diseases caused by diverse pathogens. Pots of 4-week-old plants for each line were inoculated by spraying with a suspension of conidiospores from a virulent isolate of $P$. parasitica (Emwa). The plants were maintained under $100 \%$ humidity and observed for sporulation 7 days postinoculation (dpi). The untransformed
Wassilewskija plants were susceptible to this $P$. parasiticia isolate and showed dense sporulation on leaf surfaces $7 \mathrm{dpi}$ (Fig. 1A). Three general classes of NIM1 lines were identified among the NIM1 transgenic lines: susceptible (9B and 10A), intermediate (6E and 7C), and resistant (3A, 5B, and 8C). Examples of plants demonstrating the range in responses to the inoculation are shown in Figure 1. The susceptible lines were indistinguishable in the amount of sporulation from the susceptible untransformed Wassilewskija plants (Fig. 1B). No sporulation was detected on leaves of the resistant plants, indicating a high degree of constitutive resistance to $P$. parasitica (Fig. 1D). A number of lines displayed an intermediate amount of sporulation (Fig. 1C), indicating an intermediate level of resistance. These phenotypes were very consistent in the many experiments performed during this research.

A second fungal pathogen, Erysiphe cichoracearum strain UCSC, also was used to inoculate Wassilewskija and NIM1 plants. Conidia from infected stock plants were brushed evenly onto the leaves of experimental plants, and at $10 \mathrm{dpi}$, plants were scored for disease symptoms (Table 1). The relative levels of resistance of the NIM1 plants to E. cichoracearum were similar to the results obtained with $P$. parasitica. Lines $3 \mathrm{~A}, 5 \mathrm{~B}$, and $8 \mathrm{C}$ were the most resistant, $6 \mathrm{E}$ and $7 \mathrm{C}$ had intermediate levels of resistance, and $9 \mathrm{~B}$ and $10 \mathrm{~A}$ had no increase in resistance over the parental Wassilewskija plants (Table 1; water treatment). An unpaired Student's $t$ test analysis of the values obtained for the water-treated plants indicate that the lines from the resistant and intermediate classes were different from Wassilewskija at the $95 \%$ confidence level. Lines 9B and 10A were not significantly different from Wassilewskija at the $95 \%$ confidence level.

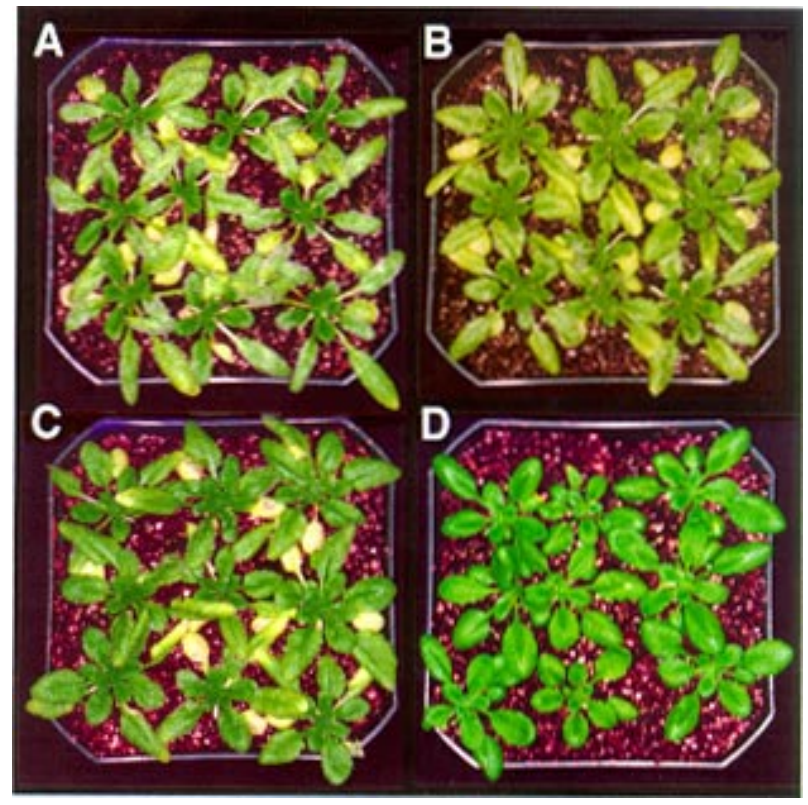

Fig. 1. NIM1 lines display a range of resistance to Peronospora parasitica. A virulent isolate of $P$. parasitica was used to score plants visually for fungal growth at 7 days postinoculation. A, Wild-type Wassilewskija plants are susceptible and develop dense sporulation. B, NIM1 lines with infection levels similar to Wassilewskija were classified as susceptible. NIM1 lines 9B and 10A were included in this class. C, NIM1 lines with less sporulation (6E and $7 \mathrm{C}$ ) were defined as intermediate. D, Plants with no visible sporulation (NIM1 lines $3 \mathrm{~A}, 5 \mathrm{~B}$, and $8 \mathrm{C}$ ) were considered resistant. 
Representative NIM1 lines (one from each of the three general classes) were then assayed for resistance to the virulent bacterial pathogen Pseudomonas syringae pv. tomato strain DC3000. Leaves injected with $P$. syringae pv. tomato were analyzed for bacterial density at different time points after inoculation. Again, line 8C, which showed the most resistance to the fungal pathogens, also was more resistant to bacterial infection. Bacterial growth measured 5 days after injection was approximately 10 times lower in the $8 \mathrm{C}$ plants $\left(1.6 \pm 0.5 \times 10^{5}\right.$ $\left.\mathrm{CFU} / \mathrm{cm}^{2}\right)$ compared with Wassilewskija plants $(3.2 \pm 0.6 \times$ $10^{6} \mathrm{CFU} / \mathrm{cm}^{2}$ ). Lines $6 \mathrm{E}$ and $10 \mathrm{~A}$, with intermediate and no enhanced resistance to the fungal pathogens, respectively, showed susceptibility to $P$. syringae pv. tomato that was similar to the susceptible parental line Wassilewskija (data not shown). Similar values were obtained in two additional experiments. Taken together, our results show that plants containing an ectopic copy or copies of the NIM1 gene can exhibit enhanced constitutive resistance to three different plant pathogens.

\section{Nucleic acid and protein analysis of NIM1 lines.}

To address the molecular basis for the range of diseaseresistant phenotypes observed in the NIM1 lines, NIM1 mRNA and protein levels were determined for homozygous transgenic plants before and after pathogen treatment. NIM1 mRNA and protein levels were constitutively elevated in all of the transgenic lines compared with untreated Wassilewskija (Fig. 2). NIM1 protein levels in the transgenic lines were up to 30 -fold higher than those in the untransformed controls (Fig. 2A) and, in general, were proportional to NIM1 mRNA levels (Fig. 2B). (A longer exposure of the Western blot showed accumulation of NIM1 protein in the 9B sample 2 days after fungal treatment, whereas very little protein could be detected in the comparable Wassilewskija sample.) Interestingly, the lines with the lowest NIM1 protein levels (9B and 10A) were the most susceptible, whereas plants that had the highest NIM1 protein levels (6E and 7C) were less resistant than lines with intermediate NIM1 protein accumulation (3A, 5B, and $8 C)$. This suggests that there may be an optimal level of NIM1 expression for maximum resistance.

To determine the possible influence of the transgene copy number on disease resistance phenotypes, DNA was isolated from Wassilewskija and NIM1 plants, digested with restric-

Table 1. Growth of Erysiphe cichoracearum on NIM1 and Wassilewskija plants $^{\mathrm{a}}$

\begin{tabular}{lccc}
\hline Line & Water & $\mathbf{5 0} \boldsymbol{\mu M} \mathbf{B T H}$ & $\mathbf{1 0 0} \boldsymbol{\mu M} \mathbf{B T H}$ \\
\hline Wassilewskija & $2.67 \pm 0.49$ & $2.50 \pm 0.51$ & $1.94 \pm 0.56$ \\
3A & $2.00 \pm 0.37$ & $1.59 \pm 0.51$ & $1.20 \pm 0.41$ \\
5B & $2.06 \pm 0.54$ & $1.31 \pm 0.48$ & $1.12 \pm 0.33$ \\
8C & $1.38 \pm 0.50$ & $1.00 \pm 0.00$ & $1.00 \pm 0.00$ \\
6E & $2.25 \pm 0.45$ & $1.38 \pm 0.50$ & $1.19 \pm 0.40$ \\
7C & $2.28 \pm 0.46$ & $1.53 \pm 0.51$ & $1.29 \pm 0.47$ \\
9B & $2.76 \pm 0.44$ & $1.67 \pm 0.49$ & $1.29 \pm 0.47$ \\
10A & $2.50 \pm 0.51$ & $1.75 \pm 0.58$ & $1.44 \pm 0.51$ \\
\hline
\end{tabular}

a Plants were treated with water or 50 or $100 \mu \mathrm{M}$ benzo(1,2,3)thiadiazole-7-carbothioic acid S-methyl ester (BTH), then inoculated with E. cichoracearum 2 days later. Ten days following pathogen treatment, plants were scored for disease symptoms: $1=0-1$ leaves infected, 2 = 2-4 leaves infected, $3=4+$ leaves infected. At least 16 plants were scored for each line and treatment. Numbers represent the averages \pm standard deviations of the scores. Treatment of plants with $300 \mu \mathrm{M}$ BTH resulted in complete resistance (a score of 1) for all lines. Two additional experiments gave similar results. tion enzymes, and subjected to DNA gel blot analysis with radiolabeled NIMI cDNA as the probe. Although only lines that showed segregation of the selectable marker indicating insertion of the T-DNA at a single locus were used, most of the transgenic lines appeared to have two to three additional
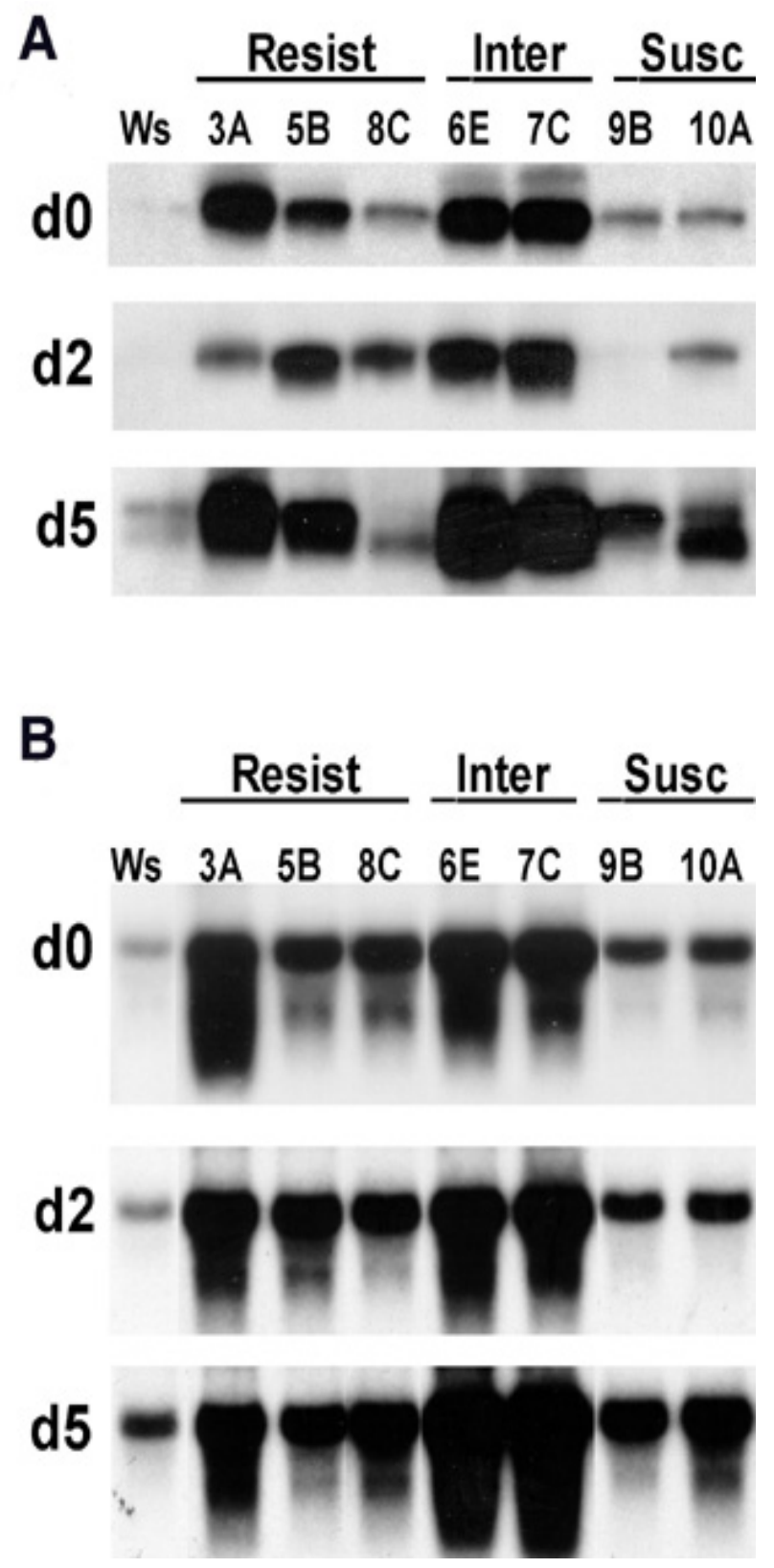

Fig. 2. RNA and protein gel blot analysis of NIM1 in Wassilewskija and NIM1 plants following Peronospora parasitica inoculation. Tissue was harvested immediately prior to inoculation (d0) as well as 2 and 5 days following (d2 and $\mathrm{d} 5$, respectively) P. parasitica inoculation and used for total RNA extraction and protein extraction. Three broadly defined classes $($ Resist $=$ resistant, Inter $=$ intermediate, Susc $=$ susceptible) are described in Figure 1. Similar results were obtained in two additional experiments. A, Total protein $(50 \mu \mathrm{g})$ per lane was subjected to protein gel analysis with antibodies raised against the C-terminal region of NIM1. B, Aliquots of RNA (10 $\mu$ g per lane) were subjected to RNA gel blot analysis with a NIM1 cDNA radiolabeled probe. Equal loading of samples was confirmed by including ethidium bromide in the sampleloading buffer, allowing for visualization of RNA under UV light. 
copies of the NIM1 gene as well as the endogenous gene (data not shown). Lines $6 \mathrm{E}$ and $7 \mathrm{C}$, which have the highest levels of constitutive NIM1 mRNA, appeared to have multiple copies of the NIMI gene at each insertion site, based on the intensity of the bands on the blot. These results suggest that the gene copy number does not correlate with the degree of resistance in the NIM1 lines.

\section{Analysis of $P R 1 \mathrm{mRNA}$ expression in NIM1 plants.}

Because NIM1 is a key regulator of the SAR pathway and some of the NIM1 lines show constitutive disease resistance that is phenotypically similar to the SAR-induced state, it is possible that SAR is constitutively activated in these plants. Alternatively, NIM1 overexpression might affect the resistance response by changing the speed or intensity of SAR induction. To distinguish between these possibilities, PRI mRNA levels were assayed in the transgenic lines to determine whether overexpression of NIMI altered the pattern of PRI expression. PRI was selected because it is a robust marker for SAR in Arabidopsis (Uknes et al. 1992). Prior to pathogen inoculation, only line $3 \mathrm{~A}$ had elevated PRI mRNA levels, whereas none of the other lines, including the constitutively resistant lines $5 \mathrm{~B}$ and $8 \mathrm{C}$, had any detectable $P R I$ expression (Fig. 3). This indicates that enhanced resistance is not dependent upon the constitutive expression of SAR genes. By 24 h after $P$. parasitica inoculation, PRl mRNA was detected in all three lines with constitutive disease resistance (3A, 5B, and $8 \mathrm{C}$ ). In lines with intermediate resistance (6E and $7 \mathrm{C})$, PRI mRNA was not detected until $2 \mathrm{dpi}$, and in lines with have no enhanced resistance (9B and 10A), $P R 1$ expression was not detected until more than $2 \mathrm{dpi}$, which is similar to the susceptible parental line Wassilewskija. Interestingly, there was no consistent correlation between the maximal level of PRI mRNA accumulation and disease resistance. For example, the maximum expression level of $P R 1$ in resistant line $8 \mathrm{C}$ was much lower than the maximum expression levels in susceptible lines 9B and 10A. Thus, in these experiments, the degree of resistance is correlated with the speed rather than the intensity of the defense response, as measured by $P R 1$ gene induction. The most resistant plants consistently accumulated PRI mRNA earlier than those with less resistance in three independent experiments.

\section{NIM1 overexpression does not alter SA accumulation.}

Elevated SA levels are associated with the disease-resistant state, and SA accumulation has been shown to be essential for the establishment of SAR (Delaney et al. 1994; Gaffney et al. 1993). The niml-1 mutation does not result in a block in the accumulation of SA in response to pathogen infection (Delaney et al. 1995), suggesting that the NIM1 gene product regulates SAR downstream of SA accumulation. There is evidence, however, for feedback regulation of SA levels from a point downstream of NIM1. For example, nim1-1 mutant plants accumulate higher levels of SA than do wild-type plants in response to infection (Delaney et al. 1995). Thus, it is possible that NIM1 overexpression could affect SA levels. The enhanced response to pathogens seen in the NIM1 plants could result from constitutively elevated levels of SA or from hyperaccumulation of SA in response to infection. Alternatively, the resistance phenotype could result from hyperresponsiveness to normally elevated levels of SA. To distinguish between these possibilities, levels of free and total SA were measured in NIM1 and Wassilewskija plants before and at 24 and $48 \mathrm{~h}$ postinoculation with $P$. parasitica. The basal SA levels remained low in all of the NIM1 lines, indicating that the enhanced resistance is not a result of constitutively elevated SA (Fig. 4). In addition, the levels of free SA in the NIM1 lines were not elevated compared with the control plants at 24 and $48 \mathrm{~h}$ postinoculation. Because NIM1 plants with constitutive resistance respond very quickly to $P$. parasitica inoculation (as indicated by $P R l$ induction within $24 \mathrm{~h}$ ), any increase in internal SA levels should be evident within this time. Free SA is rapidly glycosylated, so any transient increase in free SA levels should be reflected in total SA measurements (Enyedi et al. 1992). Although there was some variation in the total SA levels measured in the NIM1 lines compared with the Wassilewskija plants at $48 \mathrm{~h}$, there was no correlation between the total SA level and the resistance phenotype, indicating that these marginal differences are not biologically relevant. The data suggests that the increased resistance in the NIM1 lines results from enhanced responsiveness to SA or a SA-dependent signal rather than from hyperaccumulation of SA.

\section{SA mediates the NIMI overexpression phenotype.}

SA treatment causes an increase in NIMI expression, and NIM1 is required for the expression of SAR following SA treatment (Delaney et al. 1995; Ryals et al. 1997). Thus, it is possible that one of the roles for SA in SAR signaling is to induce NIM1 expression. If this is the case, overexpression of NIM1 may circumvent the requirement for SA in the estab-
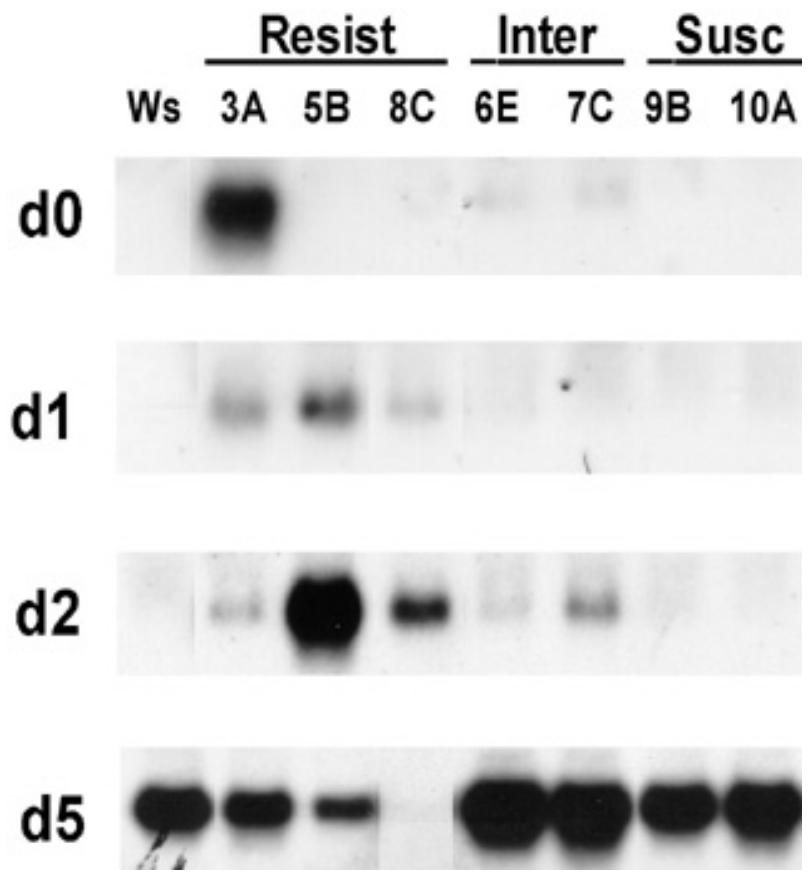

Fig. 3. $P R 1$ gene expression in Wassilewskija and NIM1 plants following Peronospora parasitica inoculation. Tissue was harvested immediately prior to inoculation (d0) as well as 1,2 , and 5 days following (d1, $\mathrm{d} 2$, and $\mathrm{d} 5$, respectively) $P$. parasitica inoculation and used for total RNA extraction. Aliquots of RNA (10 $\mu \mathrm{g}$ per lane) were subjected to RNA gel blot analysis with a PR1 cDNA radiolabeled probe. Day 0, 2, and 5 RNA samples used in this analysis were the same samples used for Figure 2B. Equal loading of RNA samples was confirmed as above. Two additional experiments gave similar results. 
lishment of disease resistance. To test this idea, three of the NIM1 lines were crossed to a Wassilewskija line expressing the bacterial nahG gene (K. Lawton, unpublished results). The $n a h G$ gene encodes for a hydroxylase that metabolizes SA, thus preventing SA accumulation and blocking the induction of SAR when expressed in Arabidopsis plants (Delaney et al. 1994). Lines expressing the $n a h G$ and the NIMI transgenes were generated and analyzed for resistance against $P$. parasitica. Expression of the $n a h G$ gene converted lines $8 \mathrm{C}$ and $5 \mathrm{~B}$ from the resistant class to the intermediate or susceptible classes (Fig. 5). For untransformed Wassilewskija and line $10 \mathrm{~A}$, some individual plants were in the intermediate and susceptible classes, whereas when crossed into the NahG background, all plants were completely susceptible. The results clearly indicate that disease resistance conferred by NIMI overexpression is abolished when the plants are unable to accumulate SA. Thus, NIMI overexpression results in en-
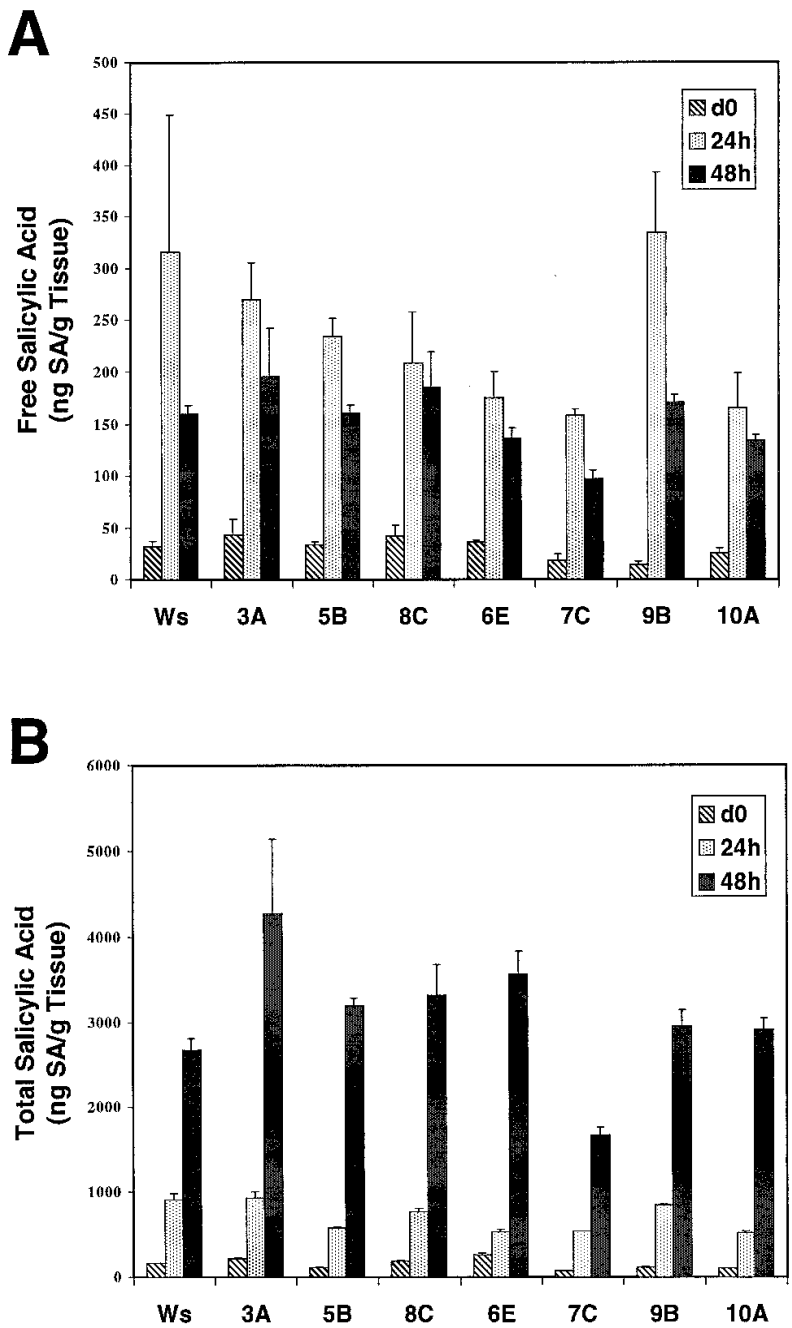

Fig. 4. Free and total salicylic acid (SA) levels in Wassilewskija and NIM1 plants after treatment with Peronospora parasitica. Tissue was harvested just prior to inoculation (d0) as well as 24 and $48 \mathrm{~h}$ following $P$. parasitica inoculation. Free and total SA extractions were performed on triplicate samples for each time point, and SA levels were determined by high-pressure liquid chromatography for each sample. Averages of the three samples for $\mathbf{A}$, free and $\mathbf{B}$, total SA levels are presented, with error bars, indicating standard deviations. hanced responsiveness either to SA itself or to a SA-dependent signal.

\section{NIM1 overexpression conditions hyperresponsiveness to chemical inducers of SAR.}

The above results indicate that $\mathrm{SA}$ is required for the heightened resistance seen in the NIM1 lines. Because SA levels in these plants are no higher than in untransformed controls, one possibility is that overexpression of NIM1 results in a heightened response to endogenous SA. Dose-response experiments were carried out to determine whether NIM1 overexpression also would result in enhanced responsiveness to the SA analog BTH. BTH is a synthetic compound that confers disease resistance in a number of plant species by activating the SAR pathway (Friedrich et al. 1996; Gorlach et al.
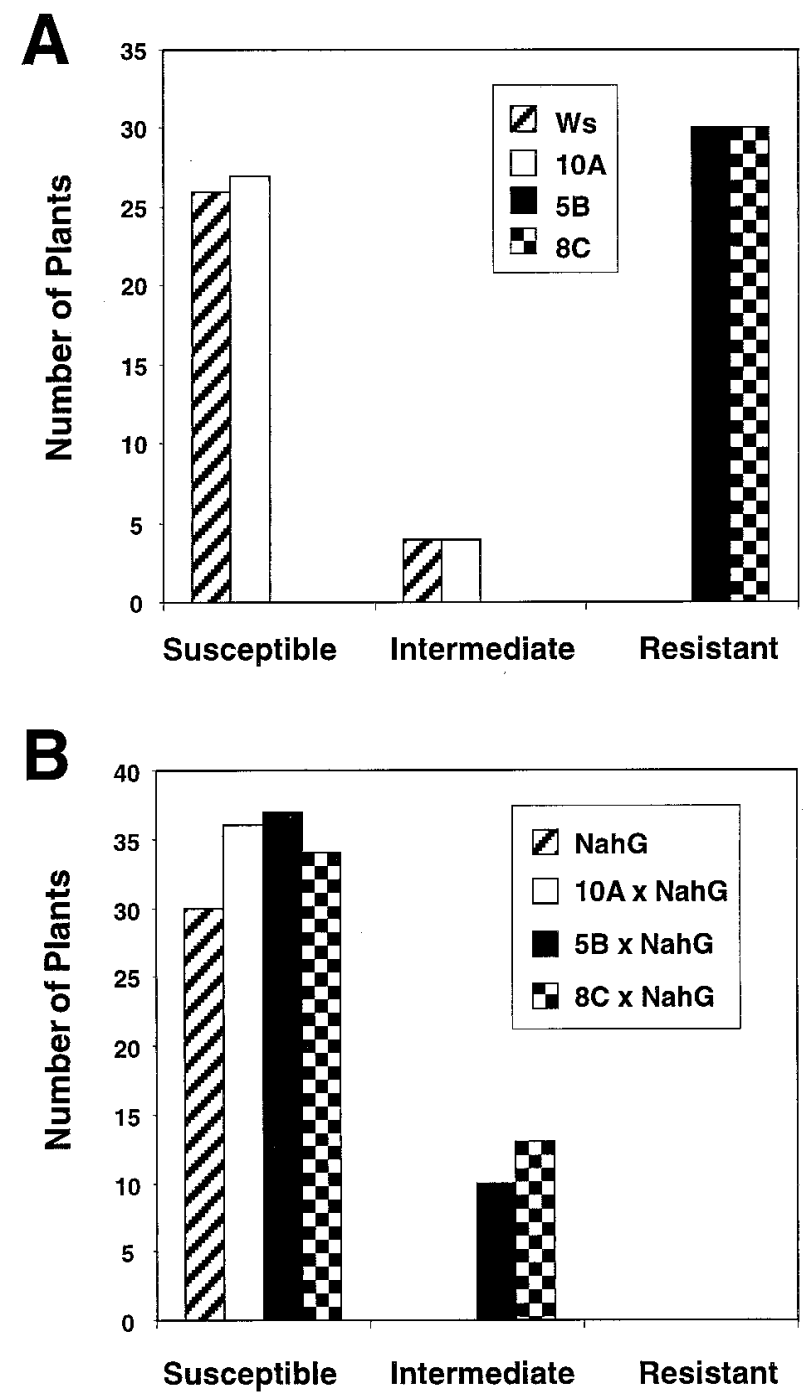

Fig. 5. Growth of Peronospora parasitica in NIM1 lines crossed with a NahG line. Plants were scored visually for sporulation 7 days postinoculation and classified as in Figure 1. A, Plants from the parental NIM1 lines 8C, 5B, and 10A and wild-type Wassilewskija show levels of infection typical for their resistance class. B, Expression of the $n a h G$ gene resulted in increased susceptibility to P. parasitica in Wassilewskija and all three NIM1 lines tested. Cumulative results from these experiments are shown. All independent experiments gave similar results. 
1996; Lawton et al. 1996). BTH acts at the same point as, or downstream of, SA in the SAR signal transduction pathway. As with SA, induction of SAR by BTH in Arabidopsis requires a functional NIMI gene (Lawton et al. 1996). Wassilewskija and NIM1 lines were treated with $10 \mu \mathrm{M}$ BTH, a concentration that does not induce SAR in wild-type plants ("subclinical dose"), or with $100 \mu \mathrm{M}$ BTH, a concentration that induces SAR gene expression and some resistance in wild-type plants ("clinical dose") (Lawton et al. 1996). SAR activation was measured by assaying $P R I$ gene expression and assaying disease resistance to normally virulent pathogens. A subclinical dose of $10 \mu \mathrm{M} \mathrm{BTH}$ induced very little $P R I$ expression in untransformed Wassilewskija plants (Fig. 6). In contrast, all NIM1 lines showed a very rapid and strong induction of $P R 1$ mRNA in response to $10 \mu \mathrm{M}$ BTH, including the most susceptible line (10A). High levels of PRI mRNA accumulated within 1 day of the $10 \mu \mathrm{M}$ BTH treatment in all transgenic lines, with a maximum increase of approximately 60-fold in the $6 \mathrm{E}$ plants. On wild-type plants, treatment with a clinical dose of $100 \mu \mathrm{M}$ BTH resulted in increases in PRI mRNA accumulation 3 and 5 days after treatment, although at levels much lower than in the transgenic plants. Thus, the NIM1 lines rapidly accumulate high levels of $P R I$ mRNA in response to BTH concentrations of at least tenfold lower than is required to induce disease resistance in wild-type plants.

NIM1 plants also were assayed for their resistance to fungal pathogens following treatment with subclinical doses of BTH. Two days after treatment with water or $10 \mu \mathrm{M} \mathrm{BTH}$, plants were inoculated with a virulent isolate of $P$. parasitica. Eight days following inoculation, leaves were harvested and stained with trypan blue to visualize fungal mycelia. Figure 7 shows
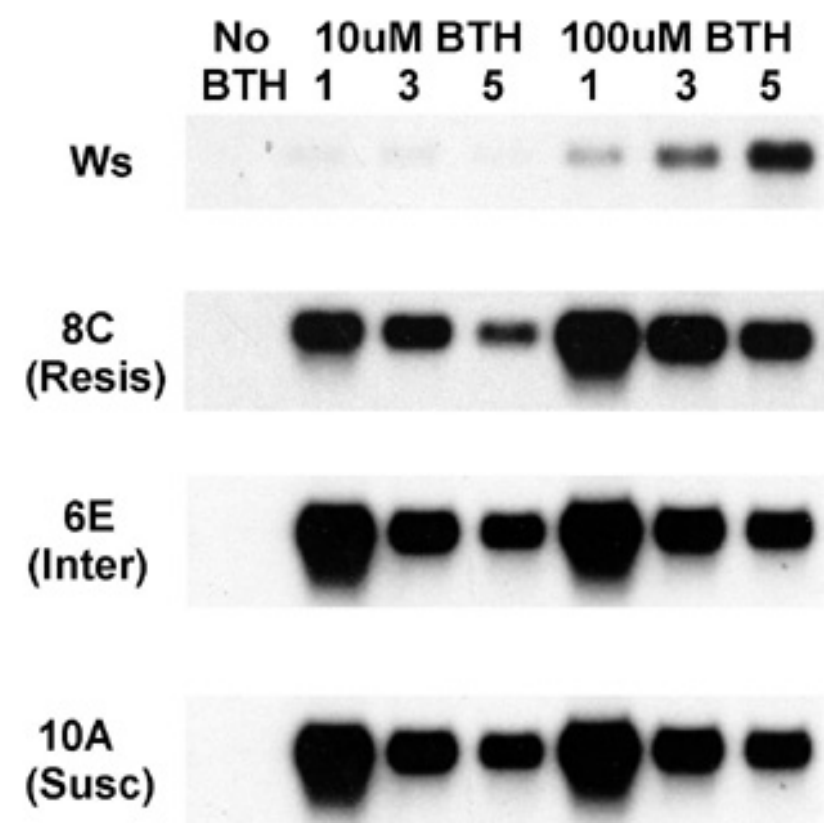

Fig. 6. $P R 1$ gene expression in Wassilewskija and NIM1 plants following benzo(1,2,3)-thiadiazole-7-carbothioic acid S-methyl ester (BTH) treatment. Total RNA was isolated from plants 1,3 , and 5 days after being treated with 10 or $100 \mu \mathrm{M}$ BTH and from control plants that had not been treated. Ten micrograms of RNA per lane was subjected to RNA gel blot analysis with a $P R 1$ cDNA radiolabeled probe. Lines $8 \mathrm{C}$, $6 \mathrm{E}$, and $10 \mathrm{~A}$ are representative of the three broadly defined classes of transgenic plants that result from NIMI overexpression. representative leaves from an untransformed Wassilewskija plant and three of the NIM1 lines. The Wassilewskija leaves were colonized extensively by the fungus following the water and BTH treatments. Consistent with our previous results (Fig. 1), line 8C showed little or no fungal growth, even with the water treatment. Lines $6 \mathrm{E}$ and $10 \mathrm{~A}$, which showed intermediate or no constitutive resistance to P. parasitica (Fig. 1), had extensive fungal growth in the water-treated leaves. No fungal hyphae were detected, however, in the leaves treated with $10 \mu \mathrm{M}$ BTH. Thus, these plants were clearly protected from fungal infection by treatment with a subclinical concentration of BTH.

NIM1 lines were inoculated with a second fungal pathogen, E. cichoracearum, following water or BTH treatments. In these experiments, a subclinical concentration of $50 \mu \mathrm{M} \mathrm{BTH}$, which did not activate resistance to E. cichoraceanum in Wassilewskija plants (Table 1, water and $50 \mu \mathrm{M}$ BTH columns), was used. Line 8C, which supported very little fungal growth after treatment with water, was protected completely by a $50 \mu \mathrm{M}$ BTH treatment. The other NIM1 lines also showed significant differences from Wassilewskija at the 95\% confidence level with an unpaired Student's $t$ test analysis for the 50 and $100 \mu \mathrm{M}$ BTH treatments. Taken together, these results indicate that overexpression of the NIM1 gene in Arabidopsis results in enhanced responsiveness to BTH for protection against two fungal pathogens.

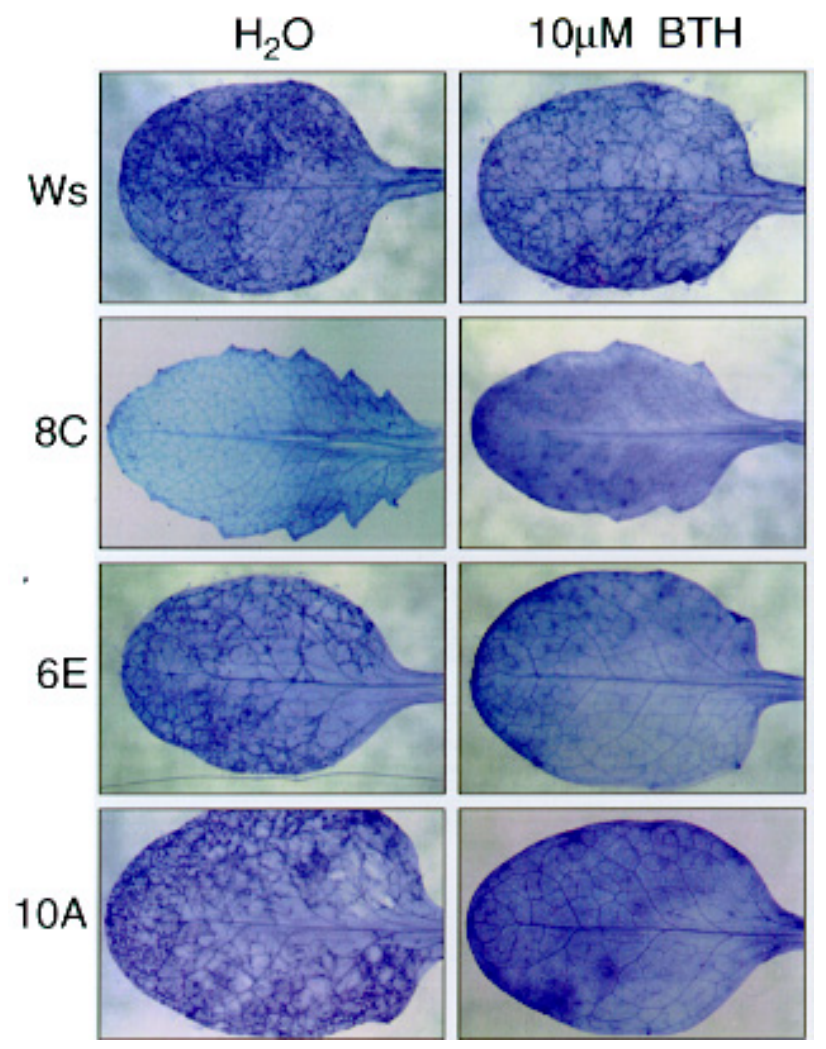

Fig. 7. Peronospora parasitica growth in benzo(1,2,3)-thiadiazole-7carbothioic acid S-methyl ester (BTH)-treated leaves. Wassilewskija and NIM1 plants were treated with water or $10 \mu \mathrm{M}$ BTH, then inoculated with $P$. parasitica. At 8 days postinoculation, leaves were harvested and stained with lactophenol trypan blue to visualize fungal mycelia. Representative leaves are from a single experiment. Staining was performed on leaves from three separate experiments, with similar results. 
Enhanced fungicide efficacy in NIM1 plants.

In a previous study, Molina et al. (1998) demonstrated that BTH treatment of plants results in a reduction in the amount of fungicide required to control a fungal pathogen compared with untreated plants. The three fungicides used in this study, metalaxyl, fosetyl, and $\mathrm{Cu}(\mathrm{OH})_{2}$, have different modes of action (Schwinn and Staub 1995). Whereas all three are effective Oomycetes fungicides, $\mathrm{Cu}(\mathrm{OH})_{2}$ is a nonselective biocide and fosetyl has activity against fungal pathogens other than Oomycetes (Schwinn and Staub 1995). To determine whether NIM1 overexpression also leads to increased fungicide efficacy, lines $6 \mathrm{E}$ and $7 \mathrm{C}$ were tested for the ability to respond to subclinical levels of these three fungicides. Lines $6 \mathrm{E}$ and $7 \mathrm{C}$ are of the intermediate resistance class, with only slightly enhanced constitutive resistance to $P$. parasitica (Fig. 1). Wassilewskija, $6 \mathrm{E}$, and $7 \mathrm{C}$ plants were treated with water or the fungicides metalaxyl, fosetyl, and $\mathrm{Cu}(\mathrm{OH})_{2}$ at various concentrations, followed 2 days later by inoculation with $P$. parasitica. At 8 dpi, tissue was harvested and total RNA was extracted. RNA analysis was performed on these samples with a fungal probe corresponding to a 555-bp region of the P. parasitica 16S-like nuclear rRNA (Molina et al. 1998), and the hybridization amount for each sample was quantified. The abundance of 16S-like nuclear rRNA in the harvested tissue was used as a measurement of fungal biomass in the infected samples.

Results of the analysis are shown in Figure 8. The level of fungal 16S-like rRNA measured in Wassilewskija plants treated with water was set as $100 \%$, and levels for the other treatments were determined by comparing the hybridization values with this standard. 16S-like nuclear rRNA levels in NIM1 lines $6 \mathrm{E}$ and $7 \mathrm{C}$ were 10 and $14 \%$ less, respectively,

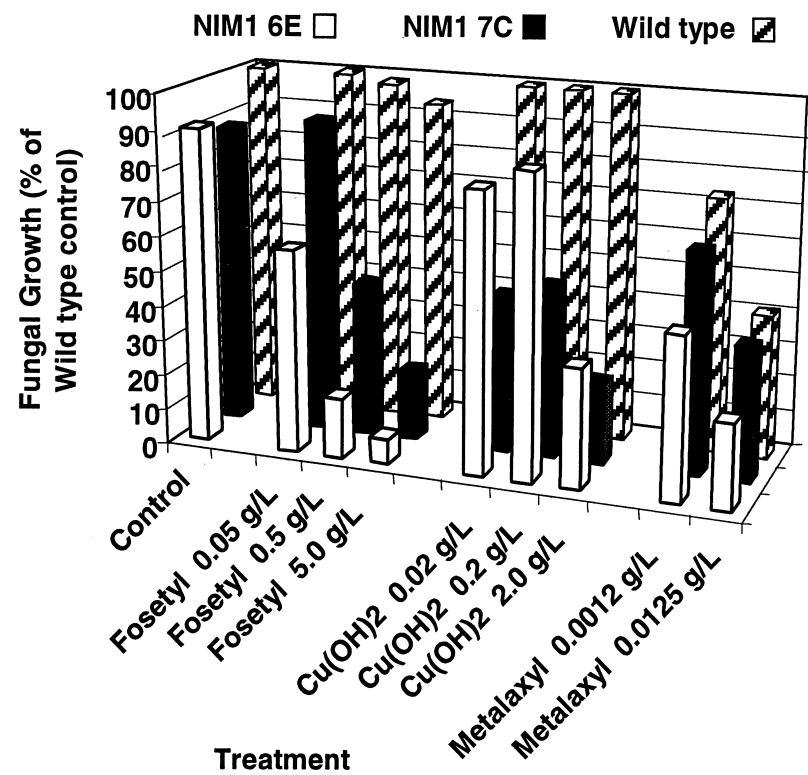

Fig. 8. Enhanced fungicide efficacy in NIM1 plants, Wassilewskija, 6E, and $7 \mathrm{C}$ plants were treated with water (control) or the fungicides metalaxyl, fosetyl, and $\mathrm{Cu}(\mathrm{OH})_{2}$ at the indicated concentrations, then inoculated with Peronospora parasitica 2 days later. At 8 days after fungal inoculation, tissue was harvested for RNA isolation and analysis, as described in text. Hybridization to a fungal probe was quantified and compared to the Wassilewskija sample treated with water, whose value was set at $100 \%$ fungal growth. Similar results were obtained in two additional experiments. than the levels of plants treated with water. Treatment with fosetyl at concentrations that caused barely any inhibition of fungal growth on the Wassilewskija plants resulted in substantial decreases in fungal growth on the NIM1 plants. At the highest concentration of fosetyl tested, there only was a $7 \%$ decrease in fungal growth in the Wassilewskija plants but a $93 \%$ decrease in the $6 \mathrm{E}$ plants and an $80 \%$ reduction for the 7C line. The $2.0 \mathrm{~g}$ of $\mathrm{Cu}(\mathrm{OH})_{2}$ per liter treatment also reduced fungal growth substantially in the NIM1 lines $(66 \%$ in $6 \mathrm{E}$ and $77 \%$ in $7 \mathrm{C}$ ), although provided no protection in the Wassilewskija plants. Results with the metalaxyl treatments were less dramatic because wild-type plants responded to very low levels of this fungicide, although the decreases in fungal growth were greater in the NIM1 lines compared with Wassilewskija. Thus, NIM1 overexpression in Arabidopsis results in enhanced efficacy to several fungicides.

\section{DISCUSSION}

Overexpression of NIM1, a key regulator of SAR in Arabidopsis, results in transgenic plants with enhanced immunity to multiple pathogens. Some of the NIM1 lines were constitutively resistant to normally virulent pathogens, in that no pretreatment was required to induce this resistance. Although these plants exhibited constitutive resistance, they did not have constitutively elevated levels of SA, and only one had constitutively elevated $P R I$ mRNA levels. Our results suggest that the mechanism for increased disease resistance in NIM1 plants is via potentiation of the SAR response by increasing sensitivity to SA or a SA-dependent signal.

In NIM1 plants treated with $P$. parasitica, we observed a strong correlation between the timing of $P R I$ induction and the degree of enhanced resistance (Fig. 3). Transgenic lines with the highest level of resistance showed the fastest induction of PRI following inoculation and, conversely, the most susceptible lines showed the slowest response. The speed of defense gene induction appeared to be more important than the magnitude of the response in determining enhanced resistance in the NIM1 lines. For example, in resistant line 8C, $P R 1$ accumulated within 1 day of inoculation, whereas in susceptible line 10A, PRI expression was not detectable until at least 3 dpi. Maximal PRI levels, however, were observed in line $10 \mathrm{~A}$ rather than in $8 \mathrm{C}$. It is likely that high $P R I$ levels observed at the later time points in the less-resistant lines is a secondary effect of extensive pathogen growth in the tissue.

Our results are consistent with a large body of work investigating the expression of $P R$ and other defense-related genes following inoculation with virulent (compatible) and avirulent (incompatible) pathogens. Compatible interactions generally result in the induction of many of the same genes as incompatible interactions, but the speed of induction is slower (Jia and Martin 1999; Van Kan et al. 1992; Voisey and Slusarenko 1989). It has been proposed that the induction of SAR is the result of the activation of inherent disease resistance mechanisms of the plant (Kuc 1982), i.e., disease occurs not as the result of a "lack of genetic information required to mount a resistance response," but rather as the result of "the inability to express the information soon enough and with sufficient magnitude to contain the pathogen" (Kuc 1982). Classical disease resistance $(R)$ genes appear to provide protection by accelerating the expression of plant resistance responses 
(Dangl and Holub 1997; Hammond-Kosack and Jones 1996; Parker and Coleman 1997). We observe that in the absence of major $R$ genes, NIMI overexpression can provide similar levels of protection against normally virulent pathogens.

SA accumulation is a key step in the SAR defense pathway in Arabidopsis. Although SA levels in the NIM1 lines did not differ significantly from those in wild-type plants, SA accumulation was required for enhanced disease resistance. When SA accumulation was prevented by the presence of the $n a h G$ transgene, enhanced resistance was abolished (Fig. 5). The requirement for SA accumulation suggests that NIM1 overexpression makes the plants more responsive to SA or a SA-dependent signal. Greater sensitivity to SA (or a SA-dependent signal) in the transgenic lines could lower the threshold level of SA required for the induction of the NIMI-dependent responses, which would then occur earlier as SA levels begin to increase following pathogen infection. This idea is reinforced by the heightened sensitivity of the NIM1 lines to subclinical concentrations of BTH, a chemical activator of SAR. BTH is similar structurally to SA and acts at the same point as, or downstream of, SA in the SAR signal transduction pathway (Lawton et al. 1996). Treatment of NIM1 lines with subclinical concentrations of BTH (10 to $50 \mu \mathrm{M}$ versus 100 to $300 \mu \mathrm{M}$ effective concentration) resulted in a very rapid and strong induction of $P R I$ as well as increased disease resistance, even in lines showing little constitutive resistance (Figs. 6 and 7 and Table 1).

We also tested the effectiveness of several fungicides on NIM1 plants to determine whether there was heightened sensitivity to these chemicals as well. Previous reports speculated that inherent defense systems in plants may contribute to the effectiveness of certain fungicides (Cartwright et al. 1977; Ward 1984). In 1998, Molina et al. showed that increased concentrations of fungicides are required for effective disease control in SAR-compromised plants (i.e., niml and $\mathrm{NahG}$ plants), implicating a role for SAR in fungicide efficacy. Our data with NIM1 plants provide additional support for this hypothesis. Fungicide concentrations that gave very limited control of a fungal pathogen on wild-type plants resulted in significant control on NIM1 plants that had only slightly enhanced constitutive resistance (Fig. 8). Thus, there was a synergistic interaction between NIMI overexpression and fungicide activity for three fungicides with different modes of action (Schwinn and Staub 1995). This suggests that the health of the plant and its ability to respond to infection affects the ability of a fungicide to control the pathogen. The NIM1 lines used in these experiments were from the intermediate resistant class and showed a faster induction of $P R I$ than the susceptible and wild-type plants. Whereas this response was not sufficient to block infection on its own, it may have slowed the infection process such that a normally subclinical concentration of fungicide was now effective.

Taken together, our data provides evidence that increasing NIM1 expression in Arabidopsis results in a potentiation or priming of the SAR response, enabling rapid deployment of disease resistance responses upon attempted pathogen ingress. Whereas NIM1 protein levels were proportional to NIM1 mRNA levels in all of the transgenic lines analyzed (Fig. 2), this did not correlate directly with enhanced disease resistance. Interestingly, the NIM1 lines with the highest levels of NIM1 protein were less resistant than some lines with inter- mediate levels, suggesting that there is an optimal level of NIM1 protein that provides effective disease resistance. It is likely that NIM1 interacts with other proteins in the SAR signal transduction pathway, and excess NIM1 protein may begin to titrate out these factors, resulting in less resistance.

One class of proteins that may interact with NIM1 is the TGA family of basic leucine zipper transcription factors. TGA genes have been identified recently with NPR1 (NIM1) as bait in a yeast two-hybrid screen (Despres et al. 2000; Niggeweg et al. 2000; Zhang et al. 1999). Some TGA proteins bind in vitro to an element in the PRI promoter that is required for induction by SA. These results suggest that TGA proteins may function with NIM1 in mediating SAR gene expression. Excessive levels of NIM1 protein may result in the formation of nonfunctional protein complexes, compromising disease resistance.

Our results differ from a previous report on overexpression of the NIMI (NPRl) gene (Cao et al. 1998) in several significant ways. Cao et al. (1998) observed a correlation between the amount of PRI accumulation and the degree of resistance in their transgenic plants, whereas we found that the timing of PRI induction rather than the magnitude was more important. They also observed a negative correlation between NIM1/NPRI mRNA and protein in some transgenic lines. For example, they described a line with a sevenfold increase in NIM1 mRNA levels but with a 25-fold decrease in NIM1 protein compared with the wild type. In all of our transgenic lines, the amount of NIM1 protein was directly proportional to the amount of NIMI mRNA. Furthermore, Cao et al. (1998) reported a maximum threefold increase of NIM1 protein levels in their transgenic lines compared with wild-type plants. On the basis of these results, they proposed that NIM1 protein accumulation may be regulated by a posttranslational cosuppression mechanism. Because we observed increases in NIM1 protein levels up to 30-fold with no obvious negative side effects, our results suggest that there is not necessarily a tight constraint on the amount of NIM1 protein produced in Arabidopsis.

The discrepancies between the two studies may reflect the differences in ecotypes and pathogen strains used. The variations also may be related to the utilization of different transgene constructs. Cao et al. (1998) transformed Arabidopsis thaliana cv. Columbia plants with the NIMI cDNA under the control of the strong Cauliflower mosaic virus $35 \mathrm{~S}$ promoter, whereas we transformed Wassilewskija plants with a genomic copy of the NIMI gene containing introns under control of its own promoter. The contributions, if any, of the promoters selected or of the introns present on NIM1 expression is unknown. It will be interesting to determine the possible regulatory contribution of the NIM1 promoter on NIM1 protein accumulation.

The results presented in this paper suggest that NIMI overexpression may be useful to develop novel and durable cropprotection strategies against a broad spectrum of pathogens. Whereas NIM1 overexpression alone can result in constitutive resistance to some pathogens, there may be a number of advantages to expressing NIMI at relatively low levels and enhancing the resistance chemically, when required. We observed no consistent negative growth effects on the transgenic Arabidopsis NIM1 plants, although this may not be the case in all species or under all growth conditions. It has been observed that constitutive expression of the SAR response can have a physiological cost (Bowling et al. 1994; Clarke et al. 1998; Yu et al. 1998). Additionally, having the pathogen popu- 
lations exposed constantly to plants that constitutively express the enhanced resistance puts selection pressure on the pathogens to adapt to colonize plants while in this state. The resistance in SAR is thought to be based on the coordinated expression of a set of genes that blocks infection and, therefore, should be very durable. Maintaining the response as inducible rather than constitutive, however, should minimize the chances of pathogens overcoming resistance. Employing a combination of NIM1 overexpression and BTH treatment also may have advantages over the use of BTH alone. Treating plants engineered to overexpress NIMI with BTH may result in more complete protection against a broader range of pathogens and, because of the enhanced responsiveness of the plants, the amount of BTH required may be significantly reduced and the response speed may be faster in plants overexpressing NIMI.

Combining NIMI overexpression with fungicide treatment to reduce the pathogen population may provide further advantages. Because fungicides are more effective on these plants, the amount required for effective disease control is reduced. This not only has environmental implications but should increase the effective life of the active ingredient of the fungicide. Pathogens can develop resistance rapidly to chemical control agents if measures are not taken to minimize the risk. For example, strobilurin fungicides were introduced in 1997 to control powdery mildew (Erysiphe graminis) on cereals in Europe. At that time, all field isolates tested were sensitive to the fungicide and disease control was good. By 1999, up to $90 \%$ of the spores sampled in some areas of northern Germany were resistant to strobilurins, with a concurrent reduction in disease control in these areas (Chin et al. 2001). Because NIMI overexpression can result in reduced pathogen growth on the plants with the use of less fungicide, the exposure of the pathogen to the active ingredient is reduced, thereby reducing the chances of the pathogen becoming resistant to the fungicide. Thus, an integrated approach incorporating NIM1 overexpression could result in crop protection that is broad spectrum and durable, while at the same time requiring less chemical input.

\section{MATERIALS AND METHODS}

\section{Plant material and generation \\ of NIM1 overexpressing plants.}

Wassilewskija (Ws-0) plants were transformed with Agrobacterium tumefaciens strain GV3101 harboring a plasmid conferring kanamycin resistance and containing the wild-type NIM1 gene, $1.4 \mathrm{~kb}$ of the NIM1 promoter, and 789 bases of sequence $3^{\prime}$ of the NIMI gene (Ryals et al. 1997) with previously described methods (Bechtold et al. 1993; Mindrinos et al. 1994). Seeds from the infiltrated plants were harvested several weeks later and allowed to germinate on germination medium (GM) agar plates containing $50 \mu \mathrm{g}$ of kanamycin per $\mathrm{ml}$ (Weymann et al. 1995). Thirty-eight surviving $T_{1}$ seedlings were selected, transferred to soil, and allowed to selfpollinate. $T_{2}$ seed from these $T_{1}$ individuals was germinated on kanamycin and on lines that showed approximately 3:1 segregation for kanamycin resistance, indicating segregation of a single T-DNA locus, and were selected for further analysis. Homozygous $\mathrm{T}_{2}$ plants were identified by selecting those that produced $100 \%$ kanamycin-resistant seed in the $\mathrm{T}_{3}$ generation. Homozygous plants were used in all subsequent analyses. Crosses of NIM1 lines $\left(\mathrm{kan}^{\mathrm{r}}\right)$ to Wassilewskija plants containing the $n a h G$ gene (hyg) were performed on half-closed flower buds from the female parent plant. $F_{1}$ progeny were selected on GM plates containing $50 \mu \mathrm{g}$ of kanamycin and $30 \mu \mathrm{g}$ of hygromycin per $\mathrm{ml}$ and subsequently selfed twice to generate $F_{3}$ lines no longer segregating for kanamycin or hygromycin resistance. SA does not accumulate in this NahG line (K. Lawton, unpublished results).

\section{Pathogen inoculations and disease resistance assays.}

To test plants for constitutive resistance to $P$. parasitica, 3to 4-week-old plants were sprayed with a conidial suspension $\left(10^{5}\right.$ spores per $\mathrm{ml}$ ), as previously described (Delaney et al. 1995). At 7 to $10 \mathrm{dpi}$, plants were scored for fungal growth and compared with Wassilewskija plants pretreated with water (high disease rating) or pretreated with $300 \mu \mathrm{M}$ BTH (uninfected). At least 10 plants per line were scored for each experiment, and all experiments were performed at least three times. For the time-course experiments, tissue was harvested just prior to inoculation (day 0), then at days 1,2 , and 5 following $P$. parasitica treatment. For microscopic analysis of fungal development, trypan blue staining was performed on individual leaves (Keogh et al. 1980) that had been treated with water or $10 \mu \mathrm{M}$ BTH 2 days prior to fungal inoculation.

Bacterial growth curve assays were performed with $P$. syringae pv. tomato strain DC3000, as previously described (Lawton et al. 1996), on 4-week-old plants. Each time point represents 10 samples, with each sample comprising three leaf discs $\left(0.5 \mathrm{~cm}^{2}\right)$ harvested from separately injected leaves.

Resistance to E. cichoracearum following water or BTH treatments were tested by brushing sporulating Wassilewskija or Columbia plants onto 4-week-old plants, as described (Frye and Innes 1998). Disease symptoms were scored 10 days later, according to the following rating: $1=$ zero to one leaves per plant infected, 2 = two to four leaves per plant infected, and $3=$ more than four leaves per plant infected. At least 16 plants were scored for each line and treatment in three separate experiments. Means and standard deviations were calculated for a single experiment.

\section{Chemical applications.}

Water or BTH in a formulation containing 50\% active ingredient was applied as a fine mist to 3- to 4-week-old plants at the indicated concentrations. Fungicides metalaxyl (N-[2,6dimethylphenyl]-N-[methyl-acetyl]), alanine methyl ester (Ridomil; Novartis, Basel, Switzerland), fosetyl (Aliette; Rhone-Poulenc, Lyon, France), and $\mathrm{Cu}(\mathrm{OH})_{2}$ (Kocide 101; Griffin, Houston, TX, U.S.A.), formulated as 25,80 , and $70 \%$ active ingredient, respectively, also were applied to 3-weekold plants at the indicated concentrations. Previous experiments showed that the wettable powder used in the formulations did not induce SAR gene expression or resistance (Molina et al. 1998).

\section{Isolation and analysis of nucleic acids.}

DNA was isolated from Wassilewskija leaves and NIM1 plants with a previously described method (Dellaporta et al. 1983). DNA gel blot analysis was performed on digested samples (10 $\mu \mathrm{g}$ per lane) from each line with the use of standard procedures (Ausubel et al. 1987). Total RNA was isolated from frozen tissue, and RNA blot hybridizations were 
performed as previously described (Ausubel et al. 1987; Lagrimini et al. 1987). Total RNA $(10 \mu \mathrm{g})$ was loaded per lane, and an equal loading of samples was confirmed by including $40 \mathrm{mg}$ of ethidium bromide per $\mathrm{ml}$ in the sample loading buffer, allowing for visualization of RNA under UV light. ${ }^{32}$ P-labeled PRI and NIMI cDNA probes (Ryals et al. 1997; Uknes et al. 1992) were synthesized with a random primer labeling system (GIBCO-BRL, Gaithersburg, MD, U.S.A.). The fungal probe was obtained as previously described (Molina et al. 1998). Hybridization and washing conditions also were performed as described (Church and Gilbert 1984). Relative amounts of the transcript were determined by quantification of the signals of the blots with a PhosphorImager (Molecular Dynamics, Sunnyvale, CA, U.S.A.), following the manufacturer's instructions.

\section{Salicylic acid extractions and analysis.}

Free and total SA analysis was conducted on leaves sampled from plants just prior to inoculation with $P$. parasitica as well as 24 and $48 \mathrm{~h}$ following inoculation. SA levels of triplicate samples were determined as described (Gaffney et al. 1993; Uknes et al. 1993).

\section{Isolation and analysis of protein levels.}

Protein was extracted by grinding frozen tissue in lysis buffer $(50 \mathrm{mM}$ Tris, $150 \mathrm{mM} \mathrm{NaCl}, 0.5 \%$ Nonidet P-40, $1 \mathrm{mM}$ dithiothreitol, and Complete Protease Inhibitors [Boehringer Mannheim, Mannheim, Germany]) as previously described (Cao et al. 1998). Protein concentrations were determined with a BCA protein assay kit (Pierce, Rockford, IL, U.S.A.). Fifty micrograms of total protein were loaded per sample onto sodium dodecyl sulfate-8\% Tris-glycine polyacrylamide gels (Novex, San Diego, CA, U.S.A.) and run according to the manufacturer's instructions. The separated proteins were electroblotted onto nitrocellulose (Towbin et al. 1979) and probed with antisera prepared against the Cterminal 75 amino acids of the NIM1 protein. The membrane was then incubated with goat horseradish peroxidase conjugated anti-rabbit antibodies (Pierce), and the chemiluminescent signal was detected with the SuperSignal West Pico kit (Pierce). X-ray film was exposed for approximately $5 \mathrm{~s}$ to obtain the image for Figure 2A. Densitometric analysis was performed with the GDS7500 gel documentation device (UVP, Upland, CA, U.SA.), and the images were analyzed with GelBase/GelBlot software (UVP), according to the manufacturer's instructions regarding estimate protein levels.

\section{ACKNOWLEDGMENTS}

We thank T. Delaney (Cornell University) for generously providing the NIM1 antisera and R. Innes (Indiana University) for kindly supplying the Erysiphe cichoracearum fungal pathogen. We also thank J. Salmeron and M. Sainz for critical review of the manuscript and H.-Y. Steiner for help with the statistical analysis.

\section{LITERATURE CITED}

Ausubel, F. M., Brent, R., Kingston, R. E., Moore, D. D., Seidman, J. G., Smith, J. A., and Struhl, K. 1987. Current Protocols in Molecular Biology. J. Wiley \& Sons, New York.

Bechtold, N., Ellis, J., and Pelletier, G. 1993. In planta Agrobacterium mediated gene transfer by infiltration of adult Arabidopsis thaliana plants. Life Sci. 316:1194-1199.
Bi, Y.-M., Kenton, P., Mur, L., Darby, R., and Draper, J. 1995. Hydrogen peroxide does not function downstream of salicylic acid in the induction of PR protein expression. Plant J. 8:235-245.

Bowling, S. A., Guo, A., Cao, H., Gordon, A. S., Klessig, D. F., and Dong, X. 1994. A mutation in Arabidopsis that leads to constitutive expression of systemic acquired resistance. Plant Cell 6:1845-1857.

Bowling, S. A., Clarke, J. D., Liu, Y., Klessig, D. F., and Dong, X. 1997. The cpr 5 mutant of Arabidopsis expresses both NPR1-dependent and NPR1-independent resistance. Plant Cell 9:1573-1584.

Cao, H., Bowling, S. A., Gordon, S., and Dong, X. 1994. Characterization of an Arabidopsis mutant that is nonresponsive to inducers of systemic acquired resistance. Plant Cell 6:1583-1592.

Cao, H., Glazebrook, J., Clarke, J. D., Volko, S., and Dong, X. 1997. The Arabidopsis NPR1 gene that controls systemic acquired resistance encodes a novel protein containing ankyrin repeats. Cell 88:5763.

Cao, H., Li, L., and Dong, X. 1998. Generation of broad-spectrum disease resistance by overexpression of an essential regulatory gene in systemic acquired resistance. Proc. Natl. Acad. Sci. USA 95:65316536.

Cartwright, D. P., Langcake, P., Pryce, J., and Leworthy, D. P. 1977. Chemical activation of host defence mechanisms as a basis for crop protection. Nature 267:511-513.

Chin, K. M., Chavaillaz, D., Kaesbohrer, M., Staub, T., Felsenstein, F. G. 2001. Characterizing resistance risk of Erysiphe graminis f. sp. tritici to strobilurins. Crop Prot. 20:87-96.

Church, G. M., and Gilbert, W. 1984. Genomic sequencing. Proc. Natl. Acad. Sci. USA 81:1991-1995.

Clarke, J. D., Liu, Y., Klessig, D. F., and Dong, X. 1998. Uncoupling PR gene expression from NPR1 and bacterial resistance: Characterization of the dominant Arabidopsis cpr6-1 mutant. Plant Cell 10:557-569.

Dangl, J., and Holub, E. 1997. La dolce vita: A molecular feast in plantpathogen interactions. Cell 91:17-24.

Delaney, T., Uknes, S., Vernooij, B., Friedrich, L., Weymann, K., Negrotto, D., Gaffney, T., Gut-Rella, M., Kessmann, H., Ward, E., and Ryals, J. 1994. A central role of salicylic acid in plant disease resistance. Science 266:1247-1250.

Delaney, T., Friedrich, L., and Ryals, J. 1995. Arabidopsis signal transduction mutant defective in chemically and biologically induced disease resistance. Proc Natl. Acad. Sci. USA 92:6602-6606.

Dellaporta, S. L., Wood, J., and Hicks, J. B. 1983. A plant DNA minipreparation: Version II. Plant Mol. Biol. Rep. 1:19-21.

Despres, C., DeLong, C., Glaze, S., Liu, E., and Fobert, P. R. 2000. The Arabidopsis NPR1/NIM1 protein enhances the DNA binding activity of a subgroup of the TGA family of bZIP transcription factors. Plant Cell 12:279-290.

Dietrich, R. A., Delaney, T. P., Uknes, S. J., Ward, E. R., Ryals, J. A., and Dangl, J. L. 1994. Arabidopsis mutants simulating disease resistance response. Cell 77:565-577.

Enyedi, A. J., Yalpani, N., Silverman, P., and Raskin, I. 1992. Localization, conjugation and function of salicylic acid in tobacco during the hypersensitive reaction to tobacco mosaic virus. Proc. Natl. Acad. Sci. USA 89:2480-2484.

Friedrich, L., Lawton, K., Ruess, W., Masner, P., Specker, N., GutRuella, M., Meier, B., Dincher, S., Staub, T., Uknes, S., Metraux, J.-P., Kessmann, H., and Ryals, J. 1996. A benzothiadiazole derivate induces systemic acquired resistance in tobacco. Plant J. 10:61-70.

Frye, C. A., and Innes, R. W. 1998. An Arabidopsis mutant with enhanced resistance to powdery mildew. Plant Cell 10:947-956.

Gaffney, T., Friedrich, L., Vernooij, B., Negrotto, D., Nye, G., Uknes, S., Ward, E., Kessmann, H., and Ryals, J. 1993. Requirement of salicylic acid for the induction of systemic acquired resistance. Science 261:754-756.

Glazebrook, J., Rogers, E. E., and Ausubel, F. M. 1996. Isolation of Arabidopsis mutants with enhanced disease susceptibility by direct screening. Genetics 143:973-982.

Gorlach, J., Volrath, S., Knauf-Beiter, G., Hengy, G., Beckhove, U., Kogel, K.-H., Oostendorp, M., Staub, T., Ward, E., Kessmann, H., and Ryals, J. 1996. Benzothiadiazole, a novel class of inducers of systemic acquired resistance in wheat. Plant Cell 8:629-643.

Greenberg, J., Guo, A., Klessig, D., and Ausubel, F. 1994. Programmed cell death in plants: A pathogen-triggered response activated coordinately with multiple defense functions. Cell 77:551-563.

Hammond-Kosack, K. E., and Jones, J. D. G. 1996. Resistance gene- 
dependent plant defense responses. Plant Cell 8:1773-1791.

Hunt, M., and Ryals, J. 1996. Systemic acquired resistance signal transduction. Crit. Rev. Plant Sci. 15:583-606.

Jia, Y., and Martin, G. B. 1999. Rapid transcript accumulation of pathogenesis-related genes during an incompatible interaction in bacterial speck disease-resistant tomato plants. Plant Mol. Biol. 40:455-465.

Keogh, R. C., Deverall, B. J., and McLeod, S. 1980. Comparison of histological and physiological responses to Phakopsora pachyrhizi in resistant and susceptible soybean. Trans. Br. Mycol. Soc. 74:329-333.

Kuc, J. 1982. Induced immunity to plant disease. BioScience 32:854860.

Lagrimini, L. M., Burkhart, W., Moyer, M., and Rothstein, S. 1987. Molecular cloning of complementary DNA encoding the ligninforming peroxidase from tobacco: Molecular analysis and tissuespecific expression. Proc. Natl. Acad. Sci. USA 84:7542-7546.

Lawton, K., Uknes, S., Friedrich, L., Gaffney, T., Alexander, D., Goodman, R., Métraux, J.-P., Kessmann, H., Ahl Goy, P., Gut-Ruella, M., Ward, E., and Ryals, J. 1993. The molecular biology of systemic acquired resistance. Pages 410-420 in: Mechanisms of Defence Responses in Plants. B. Fritig and M. Legrand, eds. Kluwer Academic Press, Dordrecht, The Netherlands.

Lawton, K., Friedrich, L., Hunt, M., Weymann, K., Delaney, T., Kessmann, H., Staub, T., and Ryals, J. 1996. Benzothiadiazole induces disease resistance in Arabidopsis by activation of the systemic acquired resistance signal transduction pathway. Plant J. 10:71-82.

Maher, E. A., Bate, N. J., Ni, W., Elkind, Y., Dixon, R. A., and Lamb, C. J. 1994. Increased disease susceptibility of transgenic tobacco plants with suppressed levels of preformed phenylpropanoid products. Proc. Natl. Acad. Sci. USA 91:7802-7806.

Mauch-Mani, B., and Slusarenko, A. J. 1996. Production of salicylic acid precursors is a major function of phenylalanine ammonia-lyase in the resistance of Arabidopsis to Peronospora parasitica. Plant Cell 8:203-212

Mindrinos, M., Katagiri, F., Yu, G.-L., and Ausubel, F. M. 1994. The A. thaliana disease resistance gene RPS2 encodes a protein containing a nucleotide-binding site and leucine-rich repeats. Cell 78:1089-1099.

Molina, A., Hunt, M. D., and Ryals, J. A. 1998. Impaired fungicide activity in plants blocked in disease resistance signal transduction. Plant Cell 10:1903-1914.

Morris, S. W., Vernooij, B., Titatarn, S., Starrett, M., Thomas, S., Wiltse, C. C., Frederiksen, R. A., Bhandhufalck, A., Hulbert, S., and Uknes, S. 1998. Induced resistance responses in maize. Mol. Plant-Microbe Interact. 11:643-658.

Niggeweg, R., Thurow, C., Weigel, R., Pfitzner, U., and Gatz, C. 2000. Tobacco TGA factors differ with respect to interaction with NPR1, activation potential and DNA-binding properties. Plant Mol. Biol. 42:775-788.

Oldroyd, G. E. D., and Staskawicz, B. J. 1998. Genetically engineered broad-spectrum disease resistance in tomato. Proc. Natl. Acad. Sci. USA 95:10300-10305.

Oostendorp, M., Kunz, W., Dietrich, B., and Staub, T. 2001. Induced disease resistance in plants by chemicals. Eur. J. Plant Pathol. 107:19-28.

Pallas, J. A., Paiva, N. L., Lamb, C., and Dixon, R. A. 1996. Tobacco plants epigenetically suppressed in phenylalanine ammonia-lyase expression do not develop systemic acquired resistance in response to infection by tobacco mosaic virus. Plant J. 10:281-293.

Parker, J. E., and Coleman, M. J. 1997. Molecular intimacy between proteins specifying plant-pathogen recognition. Trends Biochem. Sci. 22:291-296.

Repetti, P. P., and Staskawicz, B. 1998. Enhanced bacterial resistance due to overexpression of NDR1, a disease signaling component in Arabidopsis. Abstr. Int. Conf. Arab. Res. 9:537.
Ryals, J. A., Neuenschwander, U. H., Willits, M. G., Molina, A., Steiner, H.-Y., and Hunt, M. D. 1996. Systemic acquired resistance. Plant Cell 8:1809-1819.

Ryals, J., Weymann, K., Lawton, K., Friedrich, L., Ellis, D., Steiner, H.Y., Johnson, J., Delaney, T. P., Jesse, T., Vos, P., and Uknes, S. 1997. The Arabidopsis NIM1 protein shows homology to the mammalian transcription factor inhibitor IкB. Plant Cell 9:425-439.

Schwinn, F., and Staub, T. 1995. Phenylamides and other fungicides against Oomycetes. Pages 323-346 in: Modern Selective Fungicides, 2nd ed. H. Lyr, ed. Gustav Fischer Verlag, New York.

Shah, J., Tsui, F., and Klessig, D. F. 1997. Characterization of a salicylic acid-insensitive mutant (sail) of Arabidopsis thaliana, identified in a selective screen utilizing the SA-inducible expression of the tms 2 gene. Plant Cell 11:191-206.

Shah, J., Kachroo, P., and Klessig, D. F. 1999. The Arabidopsis ssil mutation restores pathogenesis-related gene expression in $n p r l$ plants and renders defensin gene expression salicylic acid dependent. Plant Cell 11:191-206.

Towbin, H., Staehelin, T., and Gordon, J. 1979. Electrophoretic transfer of proteins from polyacrylamide gels to nitrocellulose. Proc. Natl. Acad. Sci. USA 76:4350-4354.

Uknes, S., Mauch-Mani, B., Moyer, M., Williams, S., Dincher, S., Chandler, D., Potter, S., Slusarenko, A., Ward, E., and Ryals, J. 1992. Acquired resistance in Arabidopsis. Plant Cell 4:645-656.

Uknes, S., Lawton, K., Ward, E., Gaffney, T., Friedrich, L., Alexander, D., Goodman, R., Metraux, J.-P., Kessmann, H., Ahl Goy, P., GutRuella, M., and Ryals, J. 1993. The molecular biology of systemic acquired resistance. Pages 1-10 in: Plant Responses to the Environment. P. Gresshoff, ed. CRC, Boca Raton, FL, U.S.A.

Van Kan, J. A. L., Joosten, M. H. A. J., Wagemakers, C. A. M., Van den Berg-Velthuis, G. C. M., and De Wit, P. J. G. M. 1992. Differential accumulation of mRNA's encoding extracellular and intracellular PR proteins in tomato induced by virulent and avirulent races of Cladosporium fulvum. Plant Mol. Biol. 20:513-527.

Vernooij, B., Friedrich, L., Ahl Goy, P., Staub, T., Kessmann, H., and Ryals, J. 1995. 2,6-Dichloroisonicotinic acid-induced resistance to pathogens without the accumulation of salicylic acid. Mol. PlantMicrobe Interact. 8:228-234.

Voisey, C. R., and Slusarenko, A. J. 1989. Chitinase mRNA and enzyme activity in Phaseolus vulgaris (L.) increase more rapidly in response to avirulent than to virulent cells of Pseudomonas syringae pv. phaseolicola. Physiol. Mol. Plant Pathol. 35:403-412.

Ward, E. R., Uknes, S. J., Williams, S. C., Dincher, S. S., Wiederhold, D. L., Alexander, D. C., Ahl Goy, P., Métraux, J.-P., and Ryals, J. A. 1991. Coordinate gene activity in response to agents that induce systemic acquired resistance. Plant Cell 3:1085-1094.

Ward, E. W. B. 1984. Suppression of metalaxyl activity by glyphosate: Evidence that host defence mechanisms contribute to metalaxyl inhibition of Phytophthora megasperma f. sp. glycinea in soybeans. Physiol. Plant Pathol. 25:381-386.

Weymann, K., Hunt, M., Uknes, S., Neuenschwander, U., Lawton, K., Steiner, H.-Y., and Ryals, J. 1995. Suppression and restoration of lesion formation in Arabidopsis $l s d$ mutants. Plant Cell 7:2013-2022.

White, R. F. 1979. Acetylsalicylic acid (aspirin) induces resistance to tobacco mosaic virus in tobacco. Virology 99:410-412.

Yu, I.-C., Parker, J., and Bent, A. F. 1998. Gene-for-gene disease resistance without the hypersensitive response in Arabidopsis dnd 1 mutant. Proc. Natl. Acad. Sci. USA 95:7819-7824.

Zhang, Y., Fan, W., Kinkema, M., and Dong, X. 1999. Interaction of NPR1 with basic leucine zipper protein transcription factors that bind sequences required for salicylic acid induction of the $P R-1$ gene. Proc. Natl. Acad. Sci. USA 96:6523-6528. 